\title{
Patterns of Pectin Methylesterase Transcripts in Developing Stem Nodules of Sesbania rostrata
}

\author{
Sam Lievens, Sofie Goormachtig, Sylvia Herman, and Marcelle Holsters \\ Vakgroep Moleculaire Genetica, Departement Plantengenetica, Vlaams Interuniversitair Instituut voor Biotechnologie \\ (VIB), Universiteit Gent, K.L. Ledeganckstraat 35, B-9000 Gent, Belgium
}

Submitted 19 July 2001. Accepted 14 October 2001.

\begin{abstract}
Differential display was applied to the early stages of the interaction between the tropical legume Sesbania rostrata and its microsymbiont Azorhizobium caulinodans ORS571. An upregulated clone that is similar to pectin methylesterase-encoding genes was isolated (Srpme1). The fulllength sequence of Srpme1 was used to localize PME transcripts in situ during $S$. rostrata stem-nodule development. Several expression patterns were distinguished, hinting at general roles in vascular tissue development and cell division or expansion and at symbiosis-specific functions, such as uninfected cell differentiation.
\end{abstract}

Additional keywords: in situ hybridization, lateral root primordia, nodulation.

Pectin methylesterases (PMEs) catalyze the demethylation of esterified pectin, a major component of the primary wall and middle lamella of plant cells. PME activity affects the properties of the pectin matrix by influencing the calcium-pectate interactions and, thereby, the wall porosity and by reducing the apoplastic $\mathrm{pH}$, which is thought to activate local hydrolases (Moustacas et al. 1991; Steele et al. 1997). Moreover, demethylation renders pectins more susceptible to degradation by pectinolytic enzymes, such as polygalacturonases and pectate lyases (Koch and Nevins 1989). PME activity has been suggested to be important for different developmental processes in plants, such as fruit ripening (Fisher and Bennett 1991; Harriman et al. 1991), cell expansion (Moustacas et al. 1986; Nari et al. 1986), cambial growth (Micheli et al. 2000), germination of pollen and pollen tube elongation (Mu et al. 1994; Wakeley et al. 1998), separation of border cells from the root cap (Wen et al. 1999), laticifer development in opium poppy (PilatzkeWunderlich and Nessler, 2001), and pathogen defense (Collmer and Keen 1986). Recently, PMEs have been implicated in seed dormancy breakdown (Ren and Kermode 2000).

Here, we provide evidence that PMEs play a role in nodule development on Sesbania rostrata. This flooding-resistant tropical legume carries dormant adventitious rootlets along the stem. Upon inoculation with the microsymbiont Azorhizobium caulinodans, nodule primordia are formed in the cortex of the adventitious rootlets. The nodule primordia develop synchronously into stem-located, nitrogen-fixing nodules and have been used as a source of RNA for the dissection of early nodulation events by differential display (Goormachtig et al. 1995;

Corresponding author: Marcelle Holsters; Telephone +32-9-2645181; Fax +32-9-2645349; E-mail: mahol@gengenp.rug.ac.be.
Lievens et al. 2001). An upregulated partial cDNA clone, $S r d d 18$, corresponded to a PME gene (Lievens et al. 2001). We used in situ hybridizations to localize upregulated PME transcripts, and we propose a role for PMEs in the early symbiotic stages.

A full-length clone, Srpme1, was obtained by $5^{\prime}$ rapid amplification of cDNA ends (RACE) using the Marathon cDNA amplification kit (Clontech, Palo Alto, CA, U.S.A.). RNA derived from root primordia harvested 2 days after inoculation with $A$. caulinodans was taken as starting material. The antisense primers sh5 (5'-CTCAAGCCCACATGATCTACAGGCC-3') and sh6 (5'-GCCTCCGCTGCACTTGTGATGACATG-3') were used as specific SrPME1 primers. The RACE products were cloned in the pGEM-T vector (Promega, Madison, WI, U.S.A.) and the plasmid with the largest insert was designated pGEMTg51flc12mar. A fragment from the start codon to the beginning of the poly(A) tail was reconstructed with Vent polymerase (New England Biolabs, Beverly, MA, U.S.A.) in a polymerase chain reaction (PCR) amplification on the previously used cDNA template with sense primer sh24 (5'-ATGGCTAGCCAACAATCTTTGTTAGAC-3') and antisense primer $\operatorname{sh} 25$ (5'-CGAACGAAACAAAGCTTTGTTATTTAG-3'). The PCR fragment was cloned in the pGEM-T vector (Promega) and named pGEMTg51fl11.

The complete cDNA contained $1,906 \mathrm{bp}$, including a short poly(A) tail. An open reading frame of 554 amino acids was identified. In a BLASTP search (Altschul et al. 1997), the deduced protein shared $86 \%$ similarity with a PME of pea (rcpme1) (Fig. 1; Wen et al. 1999). Lower similarity levels were obtained with PMEs from tomato, sweet orange, and peach (Fig. 1). The deduced amino acid sequence of Srpme1 had the two signature motifs of PMEs: motif I ( GxYxE) with a conserved tyrosine residue, which has been proposed to play a role in the catalytic mechanism, and motif II (GxxDFIFG), an octapeptide that is located in the central part of the protein (Fig. 1; Markovič and Jörnvall 1992). A typical N-terminal eukaryotic signal peptide for extracellular targeting was present in the protein (Gaffe et al. 1997), the cleavage site of which is predicted to be between Ala33 and Leu34, according to von Heijne's rules (1983).

DNA gel-blot hybridization of $S$. rostrata DNA with the complete coding sequence as a probe (insert from pGEMTg51fl11) showed that Srpme1 is part of a gene family (data not shown). PMEs are usually members of large gene families that are regulated in response to developmental and environmental cues (Micheli et al. 1998).

RNA gel-blot analysis showed the presence of the transcripts in uninfected root primordia. Transcript levels were enhanced 2 
days after inoculation with $A$. caulinodans, remained constant during the nodule development, and decreased again in mature nodules (Lievens et al. 2001).

Transcript patterns were analyzed by in situ hybridization with the full-length sequence as a probe. Plasmid pGEMTg51fl11 was digested with SalI and NcoI to yield templates for ${ }^{35} \mathrm{~S}$-labeled antisense and sense probe production with T7 and SP6 RNA polymerase (Amersham Pharmacia Biotech, Little Chalfont, U.K.), respectively. A low background of expression covered the complete root primordium (Fig. 2A). Higher transcript levels were found in cells associated with the central vascular bundle, presumably the vascular parenchyma. The signals were strongest in the immature vascular tissue near the dormant apical root meristem (Fig. 2A). Approximately 2 days after inoculation with $A$. caulinodans, globular nodule primordia can be observed in the midcortex of the adventitious rootlet (Fig. 2B; Goormachtig et al. 1997). Transcript accumulation was associated with the new strands of vascular tissue (connecting vascular bundles) that branch from the central stele and develop toward the nodule primordia (Fig. 2B, C, and F). At 3 days after inoculation, a similar gene expression pattern was observed, but the nodule primordium had acquired an open basket shape (Goormachtig et al. 1997). Transcripts accumulated strongly in the vascular strands that surround the proximal region of the nodule primordium (Fig. 2D and E). Moreover, the expression was elevated in the cells of the infection center around the infection pockets (Fig. 2D and E). In the next stage, the central tissue of the nodule becomes zonated, with a

50

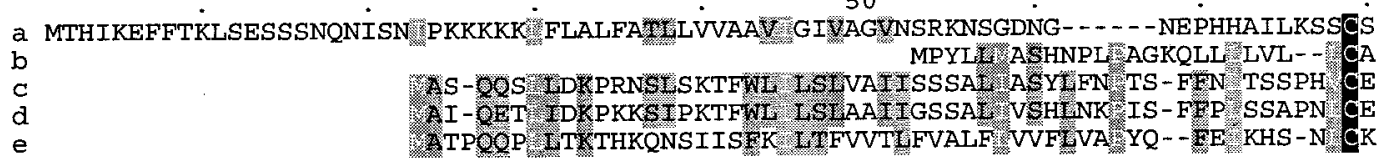

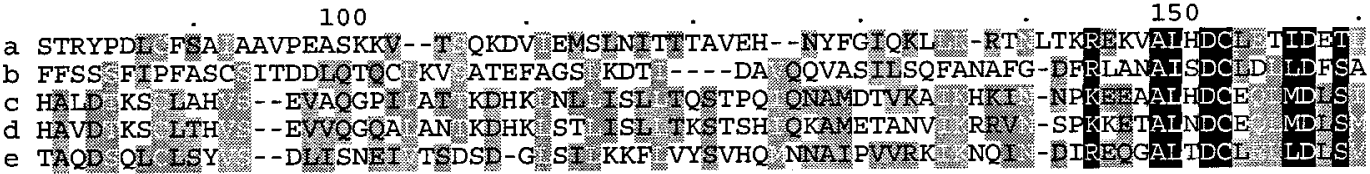

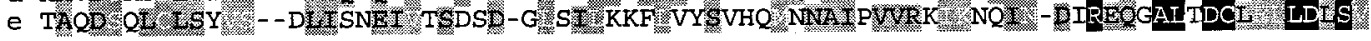
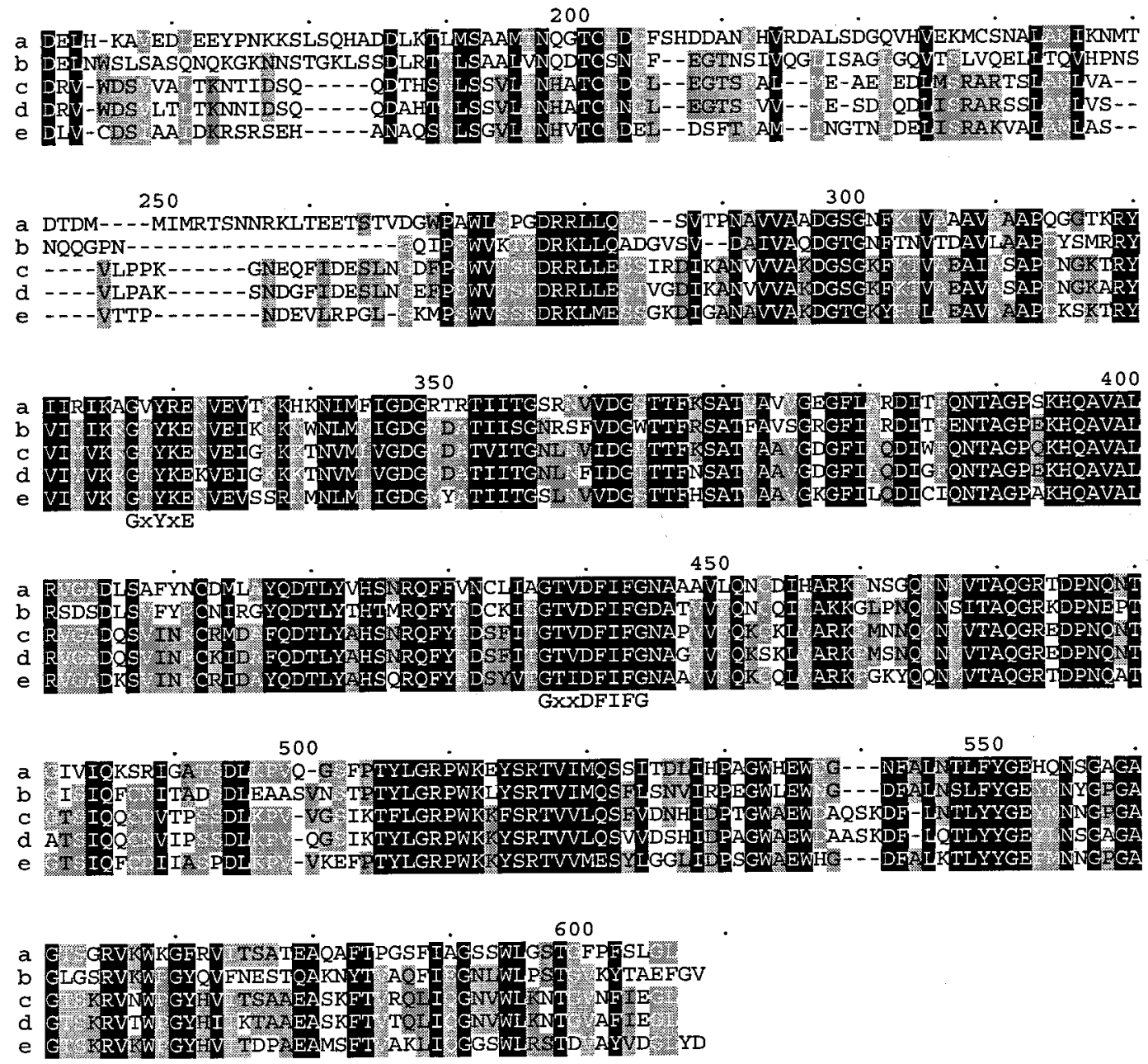

Fig. 1. Alignment of SrPME1 with pectin methylesterases (PMEs). The deduced amino acid sequence of SrPME1 (c) is aligned with PMEs from sweet orange (a; accession number T10492), peach (b; accession number Q43062), pea (d; accession number T06374), and tomato (e; accession number P09607). The conserved motifs I (GxYxE) and II (GxxDFIFG) are shown below the alignment. Gaps are indicated by dashes (-) and the amino acid residues are shaded according to the level of conservation between the different sequences. 
proximal fixation zone, an infection or invasion zone, and a distal meristem (Goormachtig et al. 1997). On longitudinal sections through a 5-day-old nodule, a complex transcript pattern was observed (Fig. 2G and H). High expression was still seen in the vascular bundles, and expression was strongest in the young distally located strands. An equally high expression was present in the central tissue, in the uninfected cells of the fixation zone, and in dispersed cells of the infection zone, presumably corresponding to those cells that are destined to remain uninfected. The first cell layer of the nodule parenchyma right next to the central tissue also showed transcript accumulation (Fig. $2 \mathrm{G}$ and $\mathrm{H}$ ). Additionally, toward the outside, the nodule meristem was surrounded by a doublelayered expression pattern. The inner layer corresponded to the developing nodule parenchyma (Fig. 2G, arrowhead), whereas the outer expression layer corresponded to the secondary meristem that forms the periderm. The activity of the nodule meristem ceases approximately 8 days after inoculation, upon which maturation takes place through cell expansion (Goormachtig et al. 1997). In these young nodules, expression disappeared, and only low transcript levels were observed in the cortical cells opposite the youngest parts of the central tissue and in the vascular bundles (Fig. 2I). In mature, 15-dayold nodules, gene expression was seen only in cells associated with the vascular tissue (data not shown).

Only a few reports are available in which PME transcript or protein distributions are visualized at the tissue level. In flax seedlings, PMEs were shown by immune fluorescence microscopy to be located in the epidermis and the xylem of the hypocotyls (Quentin et al. 1997). In orange fruits, PME transcripts and proteins were localized in the juice vesicles (Christensen et al. 1998). In the adventitious rootlets and nodules of $S$. rostrata, several patterns can be distinguished. In tomato, bean, and Arabidopsis, different PME-related genes have been shown to have distinct expression patterns in the same organ (Ebbelaar et al. 1996; Gaffe et al. 1997; Micheli et al. 1998). By analogy, the patterns observed in $S$. rostrata nodulation may correspond to the expression of more than one member of a $P M E$ gene family. Only by analyzing the promoter- $\beta$ glucuronidase fusion would it be possible to follow the individual genes. The present analysis provides a global expression profile of this group of related functions. The $\operatorname{SrPME}$ tran-
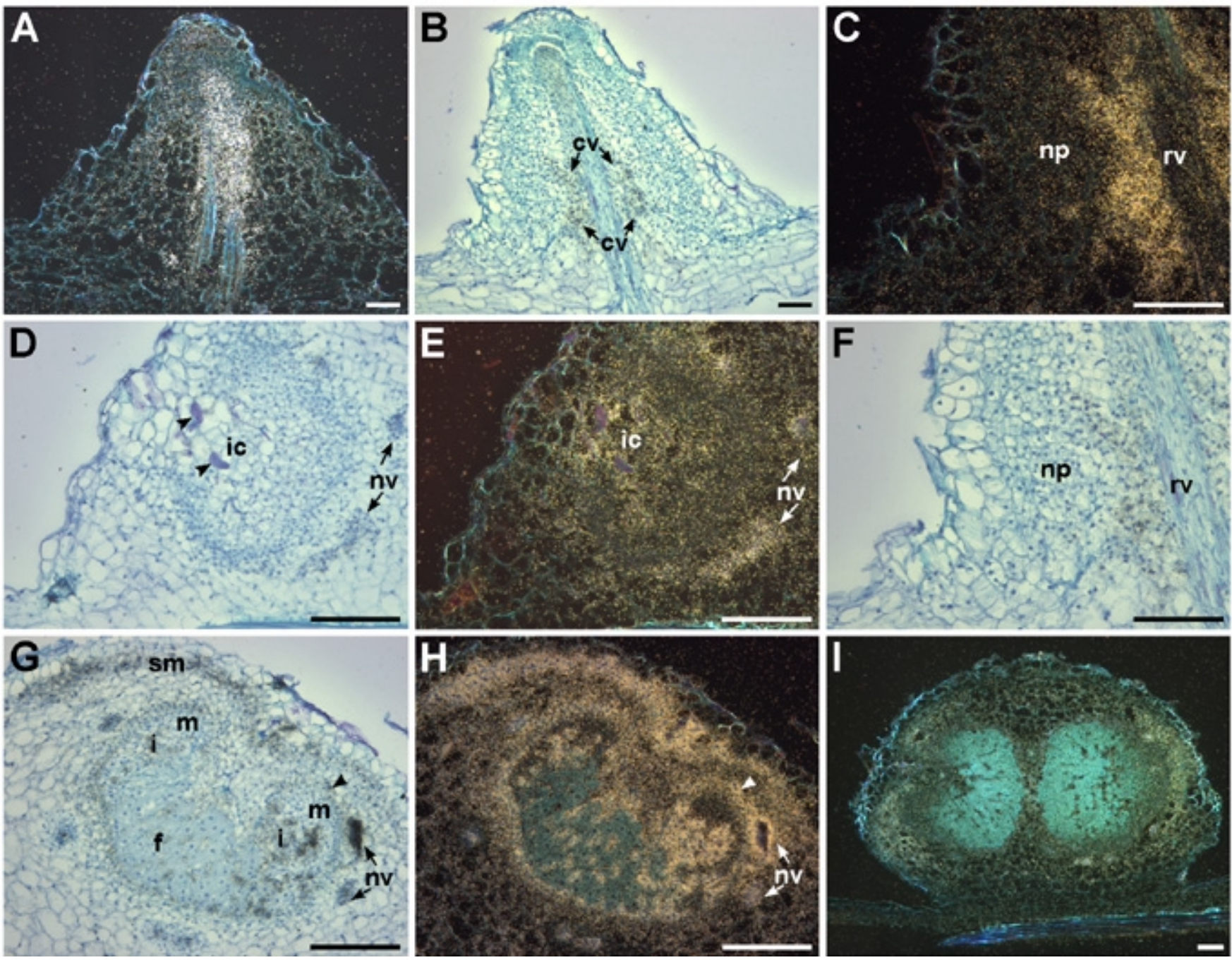

Fig. 2. In situ localization of Srpme transcripts. Longitudinal sections $(10 \mu \mathrm{m})$ through uninfected root primordia and developing stem nodules were hybridized with a ${ }^{35}$ S-labeled Srpme1 antisense RNA probe using experimental procedures described previously (Goormachtig et al. 1997). A, C, E, H, and I, are dark-field micrographs (signal seen as white spots) and $\mathbf{B}, \mathbf{D}, \mathbf{F}$, and $\mathbf{G}$, are bright-field micrographs (signal seen as black spots). A, Uninfected root primordium. B, C, and F, Developing stem nodule, 2 days after inoculation with Azorhizobium caulinodans. $\mathbf{C}$ and $\mathbf{F}$, Enlargements of (B). D and E, Developing nodule 3 days after bacterial inoculation. Arrowheads indicate infection pockets. $\mathbf{G}$ and $\mathbf{H}$, Developing nodule 5 days after inoculation. Arrowhead points at the developing nodule parenchyma containing Srpme transcripts. I, Young 8-day-old nodule. $\mathrm{cv}=\mathrm{connecting}$ vascular tissue, $\mathrm{f}=$ fixation zone, $\mathrm{i}=$ infection zone, $\mathrm{ic}=$ infection center, $\mathrm{m}=$ nodule meristem, $\mathrm{np}=$ nodule primordium, $\mathrm{nv}=$ nodule vascular tissue, $\mathrm{rv}=$ central vascular bundle of the root primordium, $\mathrm{sm}=$ secondary meristem. $\mathrm{Bar}=100 \mu \mathrm{m}$. 
scripts are mainly associated with the vascular tissues. The signal is stronger in immature strands, suggesting that PMEs may play a role in vascular tissue development. In addition to the few PMEs mentioned above, polygalacturonase transcripts are also associated with vasculature of the plant; for instance, in the developing vascular system of the radicle tip of germinating tomato seeds (Sitrit et al. 1996), in some cells of the vascular tissue of the stamen filament of maize (Dubald et al. 1993), and in the root vascular system of transgenic Vicia hirsuta (discussed below; Muñoz et al. 1998). Together, these data suggest that pectic enzymes contribute to the development of vascular tissue. A second pattern, the expression in the peripheral meristem, could be related to cell division or expansion. Indeed, pectic enzymes have been associated with rapidly growing tissues in various plant species (Pressey and Avants 1977; Sitrit et al. 1996). In maize, higher amounts of polygalacturonase transcripts were detected in small mesophyll cells than in enlarged ones (Dubald et al. 1993). In leek, antibodies against polygalacturonase bound to the meristems of lateral root primordia (Peretto et al. 1992).

Finally, a third and presumably symbiosis-specific pattern was observed in cells flanking the infection center, in nodule meristem descendents that are destined not to be infected by bacteria, in the uninfected central tissue cells, and in the first cell layer of the nodule parenchyma. The same cell types have previously been shown to harbor transcripts that correspond to a class III chitinase gene Srchil3 and a chalcone reductase gene (Goormachtig et al. 1998, 1999). Perhaps pectin methylesterase activity is important to determine the fate of the noninfected cells by altering the properties of the wall, by facilitating elicitor formation, or by other, more speculative functions (Chen et al. 2000). If true, a functional knock-out of the nodular SrPME gene would lead to the formation of nodules lacking uninfected central tissue cells.

The only other report on a pectic enzyme in symbiosis deals with a polygalacturonase Mspg3 gene from Medicago sativa (Muñoz et al. 1998). It has been proposed that the Mspg3 protein plays a role in maintaining the meristem, directing infection thread growth, and degrading cell walls during rhizobial uptake in the plant cells. Clearly, the pattern of $\operatorname{SrPME}$ expression is different, almost opposite. At present, the relative contribution of the different players in wall maintenance during nodule development remains elusive and intriguing. It should be informative to locate polygalacturonidase transcripts in $S$. rostrata nodulation. Superimposing the patterns of expression of the different pectic genes could provide a hint for differential function.

\section{ACKNOWLEDGMENTS}

The authors thank W. Ardiles and C. Buysschaert for sequencing and M. De Cock for help in preparing the manuscript. S. Lievens was a research fellow and S. Goormachtig is a postdoctoral fellow of the Fund for Scientific Research (Flanders).

\section{LITERATURE CITED}

Altschul, S. F., Madden, T. L., Schäffer, A. A., Zhang, J., Zhang, Z., Miller, W., and Lipman, D. J. 1997. Gapped BLAST and PSI-BLAST: A new generation of protein database search programs. Nucleic Acids Res. 25:3389-3402.

Chen, M.-H., Sheng, J., Hind, G., Handa, A. K., and Citovsky, V. 2000 Interaction between the tobacco mosaic virus movement protein and host cell pectin methylesterases is required for viral cell-to-cell movement. EMBO (Eur. Mol. Biol. Organ.) J. 19:913-920.

Christensen, J. H., Bauw, G., Welinder, K. G., Van Montagu, M., and Boerjan, W. 1998. Purification and characterization of peroxidases correlated with lignification in poplar xylem. Plant Physiol. 118:125-135.

Collmer, A., and Keen, N. T. 1986. The role of pectic enzymes in plant pathogenesis. Annu. Rev. Plant Physiol. 24:383-409.

Dubald, M., Barakate, A., Mandaron, P., and Mache, R. 1993. The ubiquitous presence of exopolygalacturonase in maize suggests a fundamental cellular function for this enzyme. Plant J. 4:781-791.

Ebbelaar, M. E. M., Tucker, G. A., Laats, M. M., van Dijk, C., StolleSmits, T., and Recourt, K. 1996. Characterization of pectinases and pectin methylesterase cDNAs in pods of green beans (Phaseolus vulgaris L.). Plant Mol. Biol. 31:1141-1151.

Fischer, R. L., and Bennett, A. B. 1991. Role of cell wall hydrolases in fruit ripening. Annu. Rev. Plant Physiol. Plant Mol. Biol. 42:675-703.

Gaffe, J., Tiznado, M. E., and Handa, A. K. 1997. Characterization and functional expression of a ubiquitously expressed tomato pectin methylesterase. Plant Physiol. 114:1547-1556.

Goormachtig, S., Valerio-Lepiniec, M., Szczyglowski, K., Van Montagu, M., Holsters, M., and de Bruijn, F. J. 1995. Use of differential display to identify novel Sesbania rostrata genes enhanced by Azorhizobium caulinodans infection. Mol. Plant-Microbe Interact. 8:816-824.

Goormachtig, S., Alves-Ferreira, M., Van Montagu, M., Engler, G., and Holsters, M. 1997. Expression of cell cycle genes during Sesbania rostrata stem nodule development. Mol. Plant-Microbe Interact. 10:316325.

Goormachtig, S., Lievens, S., Van de Velde, W., Van Montagu, M., and Holsters, M. 1998. Srchi13, a novel early nodulin from Sesbania rostrata, is related to acidic class III chitinases. Plant Cell 10:905-915.

Goormachtig, S., Lievens, S., Herman, S., Van Montagu, M., and Holsters, M. 1999. Chalcone reductase-homologous transcripts accumulate during development of stem-borne nodules on the tropical legume Sesbania rostrata. Planta 209:45-52.

Harriman, R. W., Tieman, D. M., and Handa, A. K. 1991. Molecular cloning of tomato pectin methylesterase gene and its expression in Rutgers, ripening inhibitor, nonripening, and never ripe tomato fruits. Plant Physiol. 97:80-87.

Koch, J. L., and Nevins, D. J. 1989. Tomato fruit cell wall. I. Use of purified tomato polygalacturonase and pectinmethylesterase to identify developmental changes in pectins. Plant Physiol. 91:816-822.

Lievens, S., Goormachtig, S., and Holsters, M. 2001. A critical evaluation of differential display as a tool to identify genes involved in legume nodulation: Looking back and looking forward. Nucleic Acids Res. 29:3459-3468.

Markovič, O., and Jörnvall, H. 1992. Disulfide bridges in tomato pectinesterase: Variations from pectinesterases of other species; conservation of possible active site segments. Protein Sci. 1:1288-1292.

Micheli, F., Holliger, C., Goldberg, R., and Richard, L. 1998. Characterization of the pectin methylesterase-like gene AtPME3: A new member of a gene family comprising at least 12 genes in Arabidopsis thaliana. Gene 220:13-20.

Micheli, F., Sundberg, B., Goldberg, R., and Richard, L. 2000. Radial distribution pattern of pectin methylesterases across the cambial region of hybrid aspen at activity and dormancy. Plant Physiol. 124:191-199.

Moustacas, A. M., Nari, J., Diamantidis, G., Noat, G., Crasnier, M., Borel, M., and Ricard, J. 1986. Electrostatic effects and the dynamics of enzyme reactions at the surface of plant cells. 2. The role of pectin methyl esterase in the modulation of electrostatic effects in soybean cell walls. Eur. J. Biochem. 155:199-202.

Moustacas, A. M., Nari, J., Borel, M., Noat, G., and Ricard, J. 1991. Pectin methylesterase, metal-ions and plant cell wall extension: The role of metal-ions in plant cell wall extension. Biochem. J. 279:351-354.

Mu, J.-H., Stains, J. P., and Kao, T.-H. 1994. Characterization of a pollenexpressed gene encoding a putative pectin esterase of Petunia inflata. Plant Mol. Biol. 25:539-544.

Muñoz, J. A., Coronado, C., Pérez-Hormaeche, J., Kondorosi, A., Ratet, P., and Palomares, A. J. 1998. MsPG3, a Medicago sativa polygalacturonase gene expressed during the alfalfa-Rhizobium meliloti interaction. Proc. Natl. Acad. Sci. U.S.A. 95:9687-9692.

Nari, J., Noat, G., Diamantidis, G., Woudstra, M., and Ricard, J. 1986. Electrostatic effects and the dynamics of enzyme reactions at the surface of plant cells. 3. Interplay between limited cell wall autolysis, pectin methyl esterase activity, and electrostatic effects in soybean cell walls. Eur. J. Biochem. 155:199-202.

Peretto, R., Favarron, F., Bettini, V., De Lorenzo, G., Marini, S., Alghisi, P., Cervone, F., and Bonfante, P. 1992. Expression and localization of polygalacturonase during the outgrowth of lateral roots in Allium porrum L. Planta 188:164-172.

Pilatzke-Wunderlich, I., and Nessler, C. L. 2001. Expression and activity of cell-wall-degrading enzymes in the latex of opium poppy, Papaver somniferum L. Plant Mol. Biol. 45:567-576.

Pressey, R., and Avants, J. K. 1977. Occurrence and properties of polygalacturonase in Avena and other plants. Plant Physiol. 60:548-553.

Quentin, M., Jauneau, A., Morvan, O., Mareck, A., Gaffé, J., and Morvan, C. 1997. Immunolocalization of pectin methyltransferases in the hypo- 
cotyl tissues of flax. Plant Physiol. Biochem. 35:475-482.

Ren, C., and Kermode, A. R. 2000. An increase in pectin methyl esterase activity accompanies dormancy breakage and germination of yellow cedar seeds. Plant Physiol. 124:231-242.

Sitrit, Y., Downie, B., Bennett, A. B., and Bradford, K. J. 1996. A novel exo-polygalacturonase is associated with radicle protrusion in tomato (Lycopersicon esculentum) seeds. Abstr. 752. Plant Physiol. Supp. 111:161.

Steele, N. M., McCann, M. C., and Roberts, K. 1997. Pectin modification in cell walls of ripening tomatoes occurs in distinct domains. Plant Physiol. 114:373-381.

von Heijne, G. 1983. Patterns of amino acids near signal-sequence cleavage sites. Eur. J. Biochem. 133:17-21.

Wakeley, P. R., Rogers, H. J., Rozycka, M., Greenland, A. J., and Hussey, P. J. 1998. A maize pectin methylesterase-like gene, ZmC5, specifically expressed in pollen. Plant Mol. Biol. 37:187-192.

Wen, F., Zhu, Y., and Hawes, M. C. 1999. Effect of pectin methylesterase gene expression on pea root development. Plant Cell 11:1129-1140. 